UDC 911.3:614(477)

Liudmyla Mykolaivna Niemets,

DSc (Geography), Professor, Head of the Department of Human Geography and Regional Studies, V.N. Karazin Kharkiv National University, 4 Svobody Sq., Kharkiv, 61022, Ukraine, e-mail: ludmila.nemets@karazin.ua, https://orcid.org/0000-0001-9943-384X;

Oksana Volodymyrivna Bartosh,

Associate Faculty, School of Humanitarian Studies, Environment, Sustainability, Royal Roads University, 2005 Sooke Road, Victoria BC V9B 5Y2, Canada, e-mail: obartosh@directions-eprg.ca;

Kateryna Yuriivna Sehida,

DSc (Geography), Associate Professor, Department of Human Geography and Regional Studies,

V.N. Karazin Kharkiv National University, e-mail: kateryna.sehida@,karazin.ua, https://orcid.org/0000-0002-1122-8460;

Kostiantyn Arkadiiovych Niemets,

DSc (Geography), Professor, Department of Human Geography and Regional Studies,

V.N. Karazin Kharkiv National University, e-mail: konnem1948@gmail.com, https://orcid.org/0000-0002-7262-2111;

Liudmyla Vasylivna Kliuchko,

PhD (Geography), Associate Professor, Department of Human Geography and Regional Studies,

V.N. Karazin Kharkiv National University,

e-mail: ludmila.klychko@karazin.ua, https://orcid.org/0000-0001-6937-3364;

Kateryna Oleksandrivna Kravchenko,

PhD (Geography), Associate Professor, Department of Human Geography and Regional Studies,

V.N. Karazin Kharkiv National University,

e-mail: kateryna.kravchenko@karazin.ua, https://orcid.org/0000-0003-4654-3185;

Ievgeniia Yuriivna Telebienieva,

PhD (Geography), Associate Professor, Department of Human Geography and Regional Studies,

V.N. Karazin Kharkiv National University,

e-mail: telebenevaev@gmail.com, http://orcid.org/0000-0002-7013-8836

\title{
HUMAN-GEOGRAPHICAL PECULIARITIES OF THE HEALTHCARE SYSTEM OF UKRAINE IN THE CONDITIONS OF MODERN CHALLENGES
}

Л. М. Немець, О. В. Бартош, К. Ю. Сегіда, К. А. Нємець, Л. В. Ключко, К. О. Кравченко, С. Ю. Телебєнєва. СУСПІЛЬНО-ГЕОГРАФІЧНІ ОСОБЛИВОСТІ СИСТЕМИ ОХОРОНИ ЗДОРОВ'Я УКРАЇНИ В УМОВАХ СУЧАСНИХ ВИКЛИКІВ. На сьогоднішній день у світі існує багато глобальних екологічних, соиіально-демографічних, економічних проблем, які створюють загрозу існування людської иивілізаиії. Однією з проблем було поширення коронавірусної інфекиії COVID-19, до якої не була готова система охорони здоров'я України, як і багатьох краӥн постсоиіалістичного простору. У ичих країнах відбуваються трансформачії в сфері охорони здоров'я, проте вони не відповідають сучасним світовим нормам та стандартам. Дане дослідження виконане на основі суспільно-географічного підходу до перебігу соиіальногеографічних процесів на прикладі трансформаиї системи охорони здоров'я з метою встановлення ключових особливостей системи охорони здоров'я України в період ї̈ трансформаиії з огляду на позитивний досвід функиіонування медичних систем країн світу, оцінки ї̈ здатності відповідати на сочіальний запит та сучасні виклики. На основі наукового аналізу зарубіжних публікачій та провідних досліджень визначено особливості, переваги та недоліки існуючих моделей систем охорони здоров'я в різних краӥнах, можливості впровадження їхніх елементів у систему охорони здоров'я Украӥни. За допомогою ретроспективного аналізу визначено особливості становлення системи охорони здоров'я Украӥни, виявлено ключові риси та принципи за системою М. О. Семашка, окреслено ї̈ позитивні та негативні риси, збережені до сьогодні. За допомогою статистичного аналізу визначено місие України серед інших країн світу за показниками розвитку системи охорони здоров'я. На основі контент-аналізу виявлено особливості трансформаиії системи охорони здоров'я Украйни, особливості запровадження реформи, їі позитивні практики та сучасні складнощі й проблеми. За допомогою SWОТ-аналізу визначено сильні та слабкі сторони системи охорони здоров'я України в умовах реформування та трансформаиї, ї̈ можливості та загрози з огляду на сучасні виклики.

Ключові слова: система охорони здоров'я, страхова медицина, Всесвітня організачія охорони здоров'я, ВВП на душу населення, Україна, постсочіалістичні країни.

Л. Н. Немец, О. В. Бартош, Е. Ю. Сегида, К. А. Немец, Л. В. Ключко, Е. А. Кравченко, Е. Ю. Телебенева. ОБЩЕСТВЕННО-ГЕОГРАФИЧЕСКИЕ ОСОБЕННОСТИ СИСТЕМЫ ЗДРАВООХРАНЕНИЯ УКРАИНЫ В УСЛОВИЯХ СОВРЕМЕННЫХ ВЫЗОВОВ. На сегодняшний день в мире существует много глобальных экологических, сочиальнодемографических, экономических проблем, которые создают угрозу сущеествованию человеческой циивилизачии. Одна из таких проблем - распространение коронавирусной инфекиии COVID-19, к которой не была готова система здравоохранения Украины, как и многих постсоциалистических стран. В этих странах происходят трансформации в сфере здравоохранения, но не всегда они отвечают современным мировым нормам и стандартам. Данное исследование выполнено на основе общественно-географического подхода к сочиально-географическим прочессам на примере трансформации системы здравоохранения с иелью выявления ключевых особенностей системы здравоохранения Украины в период трансформачии, учи(c) Niemets L. M., Bartosh O. V., Sehida K. Yu., Niemets K. A., Kliuchko L. V., Kravchenko K. O., Telebienieva le. Yu., 2021 
тывая положительный опыт функиионирования медицинских систем стран мира, оценки возможности отвечать соииальному запросу и современным вызовам. На основе научного анализа зарубежных публикаичий и ведущих исследований определены особенности, преимущества и недостатки существующих моделей систем здравоохранения в разных странах, возможности внедрения их элементов в систему здравоохранения Украины. С помощью ретроспективного анализа выявлены особенности становления системы здравоохранения Украины, определены ключевые черты и принципы по системе H. A. Семашко, ее положительные и отрицательные черты, сохранившиеся до сих пор. С помошью статистического анализа определено место Украины среди других стран мира по показателям развития системы здравоохранения. На основе контент-анализа выявлены особенности трансформации системы здравоохранения Украины, особенности внедрения реформы, ее положительные практики и современные сложности и проблемы. С помощью SWOТ-анализа представлены сильные и слабые стороны системы здравоохранения Украины в условиях реформирования и трансформации, ее возможности и угрозы учитывая современные вызовы.

Ключевые слова: система здравоохранения, страховая медицина, Всемирная организация здравоохранения, ВВП на душу населения, Украина, постсочиалистические страны.

Relevance. The XXI century brought outstanding scientific achievements in many fields of science and technology to modern civilization. It applies to nano- and nano-biotechnologies, space exploration, treatment of many previously incurable diseases, and so on. Scientists are actively working on artificial intelligence, creating highly sophisticated robotics for hazardous industries, care for the seriously ill, etc. At the same time, global ecological, sociodemographic, and economic problems are increasingly confronting human civilization with new challenges and threats to human survival.

Along with the problems of poverty, hunger, terrorism, and military conflict, the country was hit by the coronavirus infection COVID-19 in early 2020, which, starting with China, quickly spread to all continents, penetrating even Antarctica [9]. Today, the most scientifically and technologically powerful medical systems cannot overcome this threat, which turned into a real devastating pandemic. Developed countries of the world, spending huge sums on vaccines and drugs, are not able to achieve satisfactory results so far; the number of patients and deaths is growing. Moreover, the virus mutates menacingly, nullifying the scientists' efforts. As of May 10, 2021, according to the WHO, more than 3.3 million people of all ages have already died from COVID-19 and its complications, and more than 161 million people have become ill [9]. The analysis of statistics demonstrates rapid virus growth and new mutated strains will appear, in particular this situation is observed in India; its medical system does not withstand pressure and it needs for other countries' assistance. One country after another is declaring hard lockdowns, the economy is rapidly losing its potential, and the real victory over the disease is far enough. The most vulnerable countries were those with unstable economies and health care systems. Such countries include, in particular, the countries of the post-socialist and post-Soviet space. There are still transitional (transformational) processes affecting geopolitical, socio-economic, demographic aspects in many of these countries. Health care systems have not yet been transformed in accordance with world norms and standards.
Analysis of previous research. Various authors from the standpoint of different sciences widely studied the development of the health care systems in countries around the world and theirability to respond to global challenges. In particular, Lanea et al. [25] proposed potential best practices for health management systems that can be the basis for health policy development in low- and middle-income countries. Bertens and Vonk [16] analyzed the historical milestones of the formation of public-private health insurance in the Netherlands. Dózsa et al. [20] examined structural changes in the Hungarian health care system and identified the following trends: reduction of beds in emergency departments, decrease in the number of patients discharged from hospitals, reduction in the number of hospitals, change of the activity profile, one-day surgery development, development of the home health care program. Inoue et al. [22] developed a forecast model, which calculates the cost of health care by 2030, both in Japan as a whole and by individual age groups. Xiao et al. [53] analyzed the 'Healthy China' model. The implementation of this model in the country aims to provide the population with sufficient and equal access to health care in compliance with the policy of referring patients to specialists [23; 53]

Researchers also have been studying the peculiarities of the functioning and transformation of the health care system of Ukraine. In particular, Luck et al. [28], in their research «Patient and provider perspectives on quality and health system effectiveness in a transition economy: Evidence from Ukraine" considers a crucial today's issue for Ukraine and other former Soviet republics and Eastern European countries, which are in dire need of more efficient health care systems [28].

Cockerham et al., in the paper "Health lifestyles and political ideology in Belarus, Russia, and Ukraine", examined the relationship between political ideology and the practice of a healthy lifestyle and health self-assessment in Belarus, Russia, and Ukraine [18].

The National Institute for Strategic Studies, in its publications investigate the main problems and 
shortcomings of the current health care system in Ukraine [42]

Ukrainian scientists of Ivan Franko National University of Lviv Dolbneva and Goncharuk, in their paper "Necessity and main directions of improving the order of formation and use of health care resource potential in Ukraine", analyze the current state and main problems of resource provision of the health care system of Ukraine [2].

Ukrainian scientists Sazonets and Zima note the main problems of the current state of the health care system in their study "Identification of problems and main directions of reforming the health care system of Ukraine". The paper states that Ukraine's health care management system has remained virtually unchanged for a long time. The authors propose promising ways to reform the social management system of health care in Ukraine, which need an immediate solution [13].

Korniychuk in his study "Transformation of the health care system of Ukraine: Status and prospects" considers the conceptual requirements for the transformation and development of the health care system and current trends in its functioning in Ukraine [4].

In our previous studies, we have already discussed the peculiarities of the health care system functioning of the Ukraine's regions and the state as a whole [38]. Also the geographical features of social development of Donetsk region were established, the development trajectory of separate components, including health care system, was determined, the component and correlation analyses were performed [40]. We have also considered the social infrastructure development of Kharkiv region, including the role of medicine, accessibility and population security, and proposed the development trajectory for the region [24, 40, 41]. Furthermore, we also examined the issues of the development strategies of the Ukraine's regions taking into account the European experience [33, 34, 39].. However, despite significant developments in this area, the problem of finding opportunities to improve the resource potential of the medical sector at the regional and national levels remains open. In addition to identifying resources for decreasing the risks of pandemics, the challenging issue of developing sustainable regional and urban environments [35], must integrate socioeconomic, tourism [51], environmental [29], cultural [36] and technical [46] areas.

There is a need to extend the use of international standards to medical quality management systems, these standards would improve ability of the state's medical system to respond to modern societal demands and epidemiological threats. All these issues determine the feasibility and relevance of further research.
Setting goals and tasks. This publication embodies an attempt to establish the key features of the health care system of Ukraine during its transformation given the positive experience of medical systems in the world, from the positions of human geography to identify current challenges and to assess the ability to respond to social demand and the threat of the global crisis in the form of new diseases, the spread of epidemics threatening to human health, quality and life expectancy. The following tasks are set to achieve this research goal:

- based on scientific analysis of foreign publications and leading research to determine the features, advantages, and disadvantages of existing models of health care systems in different countries, the possibility of introducing their elements into the health care system of Ukraine;

- with the help of retrospective analysis to determine the features of the health care system of Ukraine, to identify key features and principles of the M. O. Semashko's system, to outline its positive and negative features preserved to this day;

- with the help of statistical analysis to determine the place of Ukraine among other countries in terms of the health care system development;

- based on the content analysis to identify the features of the transformation of Ukraine's health care system, the peculiarities of the reform, its positive practices, and current difficulties and problems;

- with the help of SWOT analysis to identify the strengths and weaknesses of the health care system of Ukraine in terms of the reformation and transformation, its opportunities, and threats given the current challenges.

Information base and research methods. The information base of the study is the statistics of the World Health Organization (WHO) on the number of beds in the world and the number of clients per doctor in a country, the World Bank statistics on the value of gross domestic product of the countries of the world and spending on health care. Analysis of the reform of the Ukraine's health care system was performed according to the information from the National Strategy for Health Care Reform in Ukraine for the period 2015 - 2020, as well as data and information from scientific papers, collections, official websites and Internet resources, reference books with special literature.

This research is conducted on the basis of human-geographical approach [8] using the following methods:

- methods of induction and deduction - for logical understanding and processing of available 
data and information on the state of the health care system of different countries;

comparison method is used at almost all stages of the study to determine the current state of the health care system of different countries and compare their development level;

- formalization method - statistical characteristics are presented in a formalized form, which allows to quantify the state of the health care system of different countries;

- analogy method allows to identify the general features of the health care system of postsocialist countries;

- methods of analysis (conditional division of an object or phenomenon into constituent parts (elements) for more detailed study) and synthesis (combination of elements of the studied object into a single whole) are used to study individual components of the health care system and formation of a holistic view of the development peculiarities of the health care system of Ukraine;

- systematization methods, including ranking and grouping allows to identify a certain order in the processes and phenomena studied, to generalize their common and distinctive features, to identify internal features and to form different groups of countries according to the economic development and current state of the health care systems and present the results of the analysis in the form of a ranked list;

- historical method studies all the changes having occurred in the health care system of Ukraine in different periods and determine the factors caused these changes;

- graphical method allows to visualize the results of the statistical database processing and calculation of indicators characterizing the state of the health care system of different countries;

- mathematical and statistical method allows to process the formed databases and calculate the necessary indicators characterizing the health care system of different countries;

- SWOT - analysis method was used to predict the development of the health care system of Ukraine, to identify strengths and weaknesses, as well as opportunities and threats to further evolution of this system.

Presentation of the main material. Today, there are several models of medical systems in the world. The practice of insurance medicine is widespread. In most countries, it is a form of social protection of the population's interests in the health care system [45]. We can distinguish models of the single-payer, compulsory insurance and hybrid system (International Healthcare Systems).

Let's examine these models of medical systems in more detail. The state pays for medical care in the single-payer model and limits the alternative mechanisms for paying services which it covers. This model is typical for Canada and Taiwan. The state and local budgets in Canada fund health care. The cost of financing Canada's health care system is $7.93 \%$ of GDP [52]. There are approximately equal share of general practitioners and narrow specialists in Canada [45].

There are public and private insurance programs in China. About 95\% of the population has at least basic health insurance. Despite this, public health insurance usually covers only about half of medical expenses, with a lower share for severe and chronic diseases. As part of the 'Healthy China 2020' initiative, China has made efforts to reduce health care costs by requiring insurance to cover $70 \%$ of costs by the end of 2018 [17, 27].

Genel Sağlık Sigortası has universal health insurance in Turkey, which is financed by a tax surcharge to employers, which is currently 5\%. Public funding covers approximately $75.2 \%$ of health expenditures [15]. The cost of financing Tyrkey's health care system is 3,2\% of GDP [52]. Genel Sağlik Sigortası covers emergencies, occupational accidents and diseases, infectious diseases, preventive medical services (drug and alcohol abuse), childbirth, infertility treatment for women under 39, cosmetic surgery deemed medically necessary [31].

Albania's universal health care system is based on both mandatory and voluntary contributions, supplemented by funding from the state budget [32]. The cost of financing Albania's health care system is 2,8\% of GDP [52]. The Albanian Constitution guarantees the right for health insurance for Albanian citizens. From 2008, patients have to pay a small fixed surcharge for visiting primary health care centers or specialized hospital treatment [47].

There is a mandatory payroll tax in Romania, which the country uses to provide for the entire population. In addition to health insurance, the government also operates most hospitals in the country, many of them need modernization. The cost of financing Romania's health care system is $4,43 \%$ of GDP [52]. A number of medical services are paid for by citizens at their own expense [30]. Every Romanian citizen is entitled to free, unlimited medical procedures prescribed by a doctor only if the insurance is confirmed. Citizens of the European Union, together with Romanian citizens who do not pay for insurance, are entitled to free emergency medical care [21].

There is a state insurance system in Poland operating as a state health care system (Narodowy Fundusz Zdrowia) and it is free for all Polish citizens, provided that they fall into the category of "insured". The cost of financing Poland's health care 
system is $4,5 \%$ of GDP [52]. Private medical care is also widespread in Poland [19].

The model of the compulsory insurance (the government requires the purchase of health insurance from private and public insurance companies) operates in Germany, Japan, the Netherlands, and Switzerland. In Germany, citizens receive insurance in "Sickness Funds", regulated by the Statutory Health Insurance System (SHI). Physicians participating in SHI must join regional associations that have entered into agreements with Sickness Funds. At the same time they are allowed to take private patients. Almost half of the hospitals are public [45]. The cost of financing Germany's health care system is $8,8 \%$ of GDP [52].

Mandatory Health Insurance (MHI) and a market-based approach to health care are combined in Switzerland. All Swiss residents must have a health insurance policy. State insurance covers most doctors and some prevention services. The cost of financing Switzerland's health care system is 3,7\% of GDP [52]. Voluntary insurance services are provided by health insurance funds, which allows receiving better medical services. Doctors are allowed private practice $[5,45]$.

There is a system of general compulsory health insurance in Japan, which is usually associated with the work place, consists of private and public insurance companies. The cost of financing Japan's health care system is $9,2 \%$ of GDP $[5,52]$.

Two statutory forms of insurance cover health care in the Netherlands: Zorgverzekeringswet (Zvw), often referred to as "basic insurance", which covers general health care; and Algemene Wet Bijzondere Ziektekosten (AWBZ) covers long-term treatment [48]. The cost of financing the Netherlands' health care system is $6,48 \%$ of GDP [52].

The hybrid system combines elements of single-payer systems with private insurance; the government provides a standard set of services for all citizens with the possibility of supplementing private insurance. These include countries such as UK, France, Singapore, USA.

There is a National Health Service in $U K$, which provides health care to British. Health services are free, financed by tax revenues. The cost of financing UK's health care system is 7,86\% of GDP [52]. In the UK most medical workers are civil servants [5].

In France the universal health insurance is enshrined, it is provided with a reliable system of insurance funds. They are usually tied to jobs and they are private companies regulated and controlled by the state [5]. The cost of financing France's health care system is $8,26 \%$ of GDP [52].

There is a National Health Plan in Singapore, which has three funds: Medisave (mandatory savings account with tax-free contributions), MediShield (covers catastrophes) and Medifund (additional program for the poor). Additional insurance is also possible. Most hospitals are state-owned and subsidized from the state budget $[5,45]$. The cost of financing Singapore's health care system is $2,25 \%$ of GDP [52].

Citizens are insured under various systems in USA. A significant number of citizens are allowed to be uninsured. Most Americans are insured through an employer, who bears a substantial portion of the costs, and insurance is not subsidized [49]. There is the Medicare program, a state-funded insurance program for the poor that is funded by federal and state revenues. $70 \%$ of hospitals are non-profit, $15 \%$ are commercial and 15\% are public [45]. The cost of financing USA's health care system is $8,5 \%$ of GDP [52].

Therefore, all models of health care financing systems in the world can be represented by four options:

- a model that operates in Germany, France, Belgium, the Netherlands, Japan, Switzerland and some Latin American countries, the so-called Bismarck's model. Features of the model: most medical institutions are private, medical services are paid for by the employee insurance fund, which is financed jointly by employers and employees through payroll deductions;

- a model operating in Canada, Taiwan and South Korea. This system has elements of the two previous models. It provides medical services by private providers, but payment is made through the state insurance program, which every citizen pays. National health insurance plans also control costs by limiting reimbursement for certain medical services or forcing patients to wait for treatment;

- a model of direct payment, used in many developed countries for certain services, as well as all countries for the purchase of over-the-counter drugs. Medical care is paid by consumers directly to health care providers;

- a model operating in the UK, Spain, mostly Scandinavia and New Zealand - the Beveridge's model. Features of the model: most medical institutions are public, medical care is provided and financed by the government through taxes, the patient does not pay for medical services [14]. Many developed countries - Sweden, Ireland, Great Britain, Denmark, Italy and others - have created their budget health care systems, which still operate, similar to the first Semashko's system created in the USSR.

The Semashko's system was developed and implemented in the Soviet Union under the M. O. Semashko's leadership. Various versions of this system 
have been used throughout the world, mainly in the former socialist bloc countries. The experience of building a M. O. Semashko's system was carefully studied and used in the design of a similar Beveridge's system [6].

The M. O. Semashko's system was based on the following principles:

- Free general medical care, which was declared a citizen's right under the constitution. All citizens, regardless of age, social status and financial well-being, received the right to qualified medical care and this right was guaranteed by the state [6];

- The state created a special structure - the Ministry of Health for the practical implementation of these guarantees. All polyclinics, hospitals and other health care institutions are state-owned enterprises, and all doctors are civil servants; funding was directly from the state budget [6]. Considerable attention was also paid to the creation of a disease prevention system, which M. O. Semashko gave a leading role in the organization of a new health care system: in 1918 a medical education center was established, which was transformed into a medical institute in 1930;

- Prevention and social hygiene were declared a priority development of the state health policy;

- It was proposed to organize medical care on two main principles: precinctal and hierarchical. primary care was provided by specialists of general profile, diagnosis and treatment of most common diseases at the grassroots level (FAP, therapeutic area and district hospital) [26]; more complex cases were transferred to regional, republican and allUnion institutes and hospitals by means of the referrals system [44]. Training of specialists in medical institutions of higher education and technical schools was also aimed at this.

In 1991, with independence, Ukraine inherited from the USSR an extensive but fairly tightly centralized health care system, based on the Semashko's system, a model of the national health care system in which health services were provided by a hierarchical system of public institutions merged into the Ministry of Health and funded from the national budget [26] This system provided an acceptable level of medical care needed to treat the most common diseases at that time and provided comprehensive coverage of the population with health services and preventive measures. To ensure financial protection of the population and improve its health, the Government of Ukraine has implemented a transformational reform of the health care system by modernizing the outdated health care system, increasing its efficiency to improve public access to quality health services since 2015. Therefore, the priority task of reforming the medical system of Ukraine is to change its funding to stimulate the introduction of information technology, to accelerate transformations in the provision of medical services and so on. The Law of Ukraine "On State Financial Guarantees of Medical Care" [12] was adopted in 2017, which regulates the financing of the health care system, establishment of the National Health Service of Ukraine (NHSU) [50].

For the first time in the history of Ukraine, funds from the state guaranteed package of medical services can be provided to private medical institutions and private doctors. Patients were able to freely choose a general practitioner - family doctor, therapist and pediatrician, regardless of the place of registration by signing the declaration. Doctors have become a key source of funding for primary care, as the budget of medical institutions now depends on the number of signed declarations [3]. One doctor has about two thousand patients.

As noted, Ukraine's health care system is currently in the process of transformation, as the "old" system is no longer working, and the "new" system has not been fully viable. The acute problem for Ukraine is the lack of professional training of infectious disease doctors, who have virtually ceased to graduate since the reforms of 2017 [10]. In addition, the system of medical education and continuous professional development is being reformed in Ukraine. The system of advanced doctors training has changed significantly.

However, notwithstanding some positive reforms of the health care system of Ukraine, the medical system still has many problems that have been significantly exacerbated during the global pandemic COVID-19. According to statistics from the WHO, medicine in the world is becoming more expensive every year in developing countries by an average of $6 \%$ annually, in developed countries - by $4 \%$. In 2019, the cost of medicine in the world amounted to $10 \%$ of global gross domestic product, and the growth rate of expenditures outpaces the growth rate of the world economy [9]. At the same time, the volume of domestic general government health expenditure (GGHE-D) as a percentage of gross domestic product (GDP) (\%) varies significantly from country to country: from $0.4-0.8 \%$ in Bangladesh, Afghanistan and a number of African countries up to $8-10 \%$ in France, Denmark, USA, Norway, Germany, Japan, Sweden, Cuba and reaches a maximum value of $15 \%$ in Tuvalu [9]. Our analysis shows a common trend for European and post-Soviet countries (Fig. 1), as the health care expenditures are positively correlated with the country's GDP. More than 7\% expenditures for health care system in Iceland, Finland, Austria, Belgium, United Kingdom, France, Denmark, Norway, Germany, Sweden; GDP per population is $40-80$ thousand dollars in these countries. It is worth noting 
Luxembourg, Switzerland, and Ireland as countries with a high level of GDP per population (above 77.5 thousand dollars), but with a low share of funding for the health care system: 3,5-5\%. Most countries in the post-Soviet space have low GDP per population and a share of spending on the health care system. It is worth focusing on the total expenditure of GGHE-D per population, which is shown in the figure by weight bubble. Thus, the largest funds per capita are in Luxembourg, Sweden, Denmark, Iceland, Norway (5-6 thousand US dollars); in Switzerland, United Kingdom, Netherlands, France, Finland, Belgium, Austria, Ireland, Germany (3-4 thousand US dollars) in 2019. Therefore, the indicator of the share of domestic total public expenditures on health care in GDP and, most importantly, the population's provision with these expenditures correlates with the development level of the world. The governments of highly developed countries understand that sustainable socio-economic development is possible under the condition of a healthy nation, which requires significant allocations to the health care. Regarding the statistical indicators of Ukraine, the per capita expenditures amounted to 110 US dollars in 2019; expenditures on the health care system was $3.7 \%$, and GDP per population was about 3 thousand US dollars.

Consider the distribution of European and post-

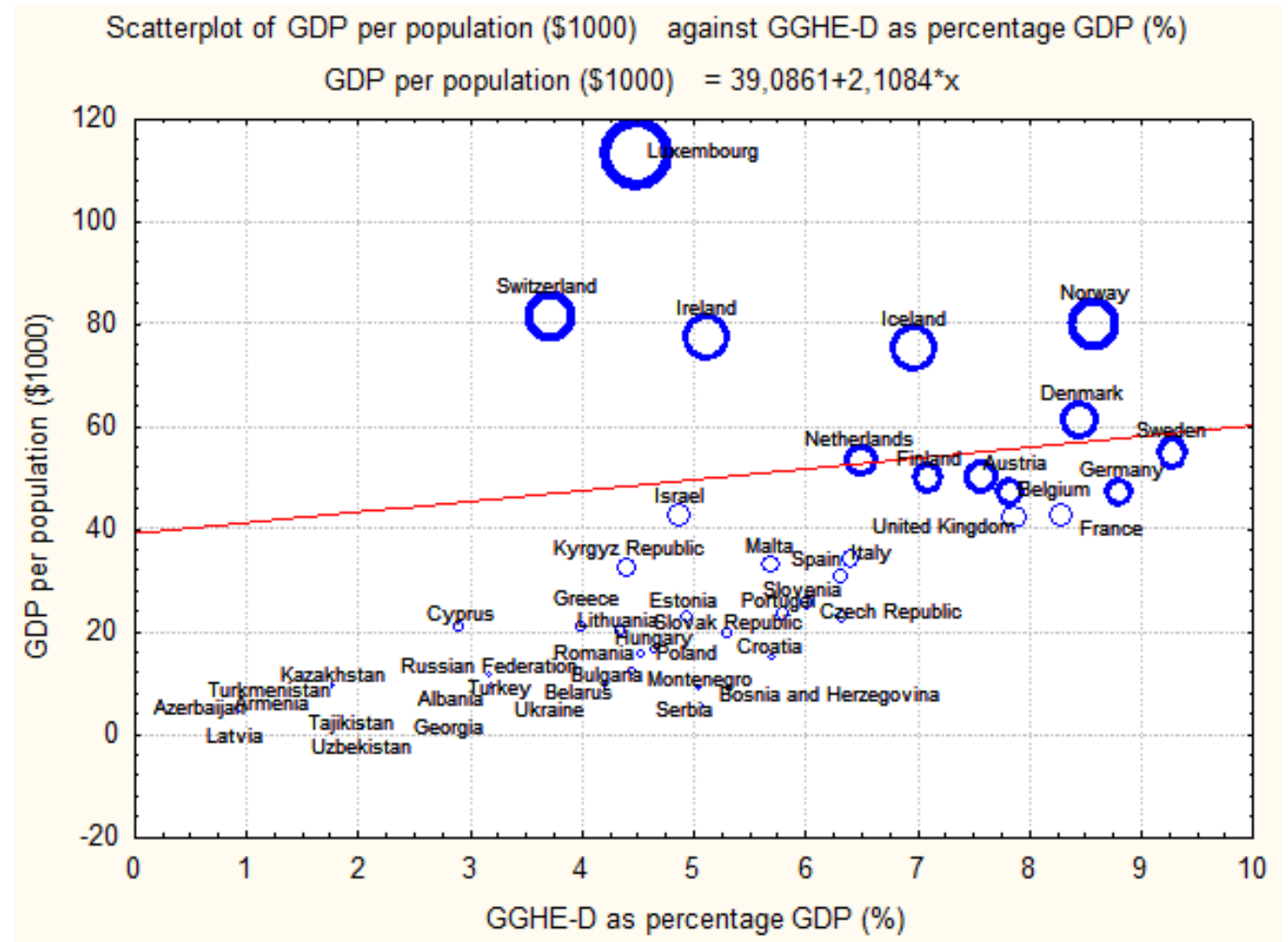

Fig. 1. Distribution of European and post-Soviet countries by GDP and share of expenditures on the health care system (constructed by $[9,52]$ )

Soviet countries in terms of the population provision with doctors in accordance with the share of domestic general government expenditures with GDP per population, as shown in the figure 2 by weight bubble. While a positive relationship between doctors provision and the share of spending on the health care system can be identified as a general trend, the doctors provision does not have a clear direct correlation with the amount of funding for health care system per population. More than 50 doctors per 10000 population are in Lithuania, Belarus, Austria, Portugal, Israel, the United Kingdom of Great Britain and Northern Ireland, Belgium, Greece, France; with the highest rates of 70 and 80 in Georgia and Italy, respectively. Countries such as Luxembourg and Ireland, with high GGHE-D expenditures per population characterizes a low provision of doctors (30-32 medical doctors per 10000 population). Regarding the statistical indicators of Ukraine, the provision of the population with doctors is 30 medical doctors per 10000 population.

Consider the distribution of European and postSoviet countries in terms of the population provision with hospital beds in accordance with the share of domestic general government expenditures with GDP per population, as shown in the figure 3 by weight bubble. Higher provision of hospital beds is observed for countries with low funding for health care system. Exceptions are Germany, Austria, France, Belgium, where GGHE-D is high and the number of hospital beds is $55-80$ per 10000 population. The highest security rate among the surveyed 
Scatterplot of Medical doctors (per 10000 population) against GGHE-D as percentage GDP (\%) Medical doctors (per 10000 population) $=25,0024+2,8768^{*} x$

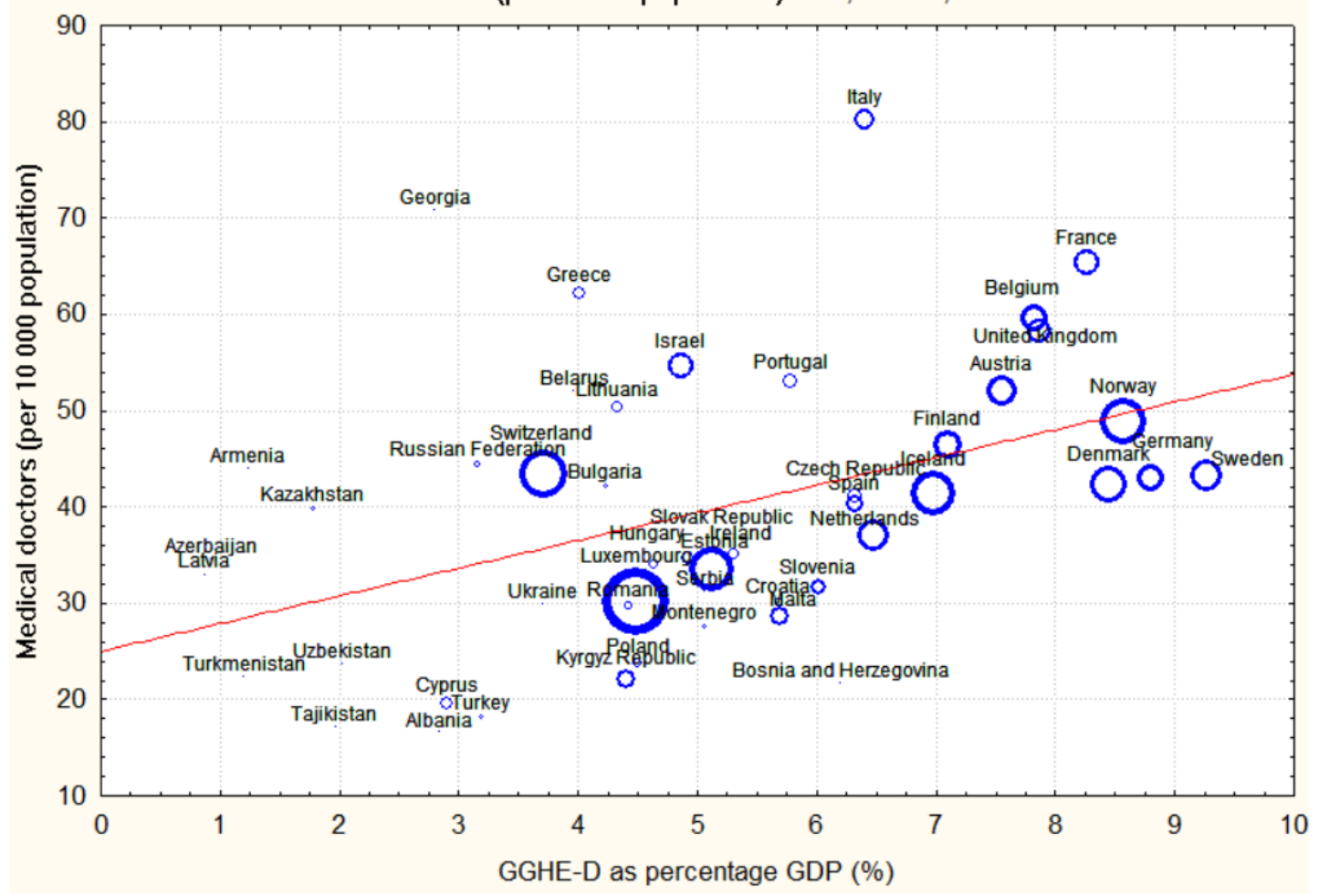

Fig. 2. Distribution of European and post-Soviet countries by a number of medical doctors and share of expenditures on the health care system (constructed by [9, 52])

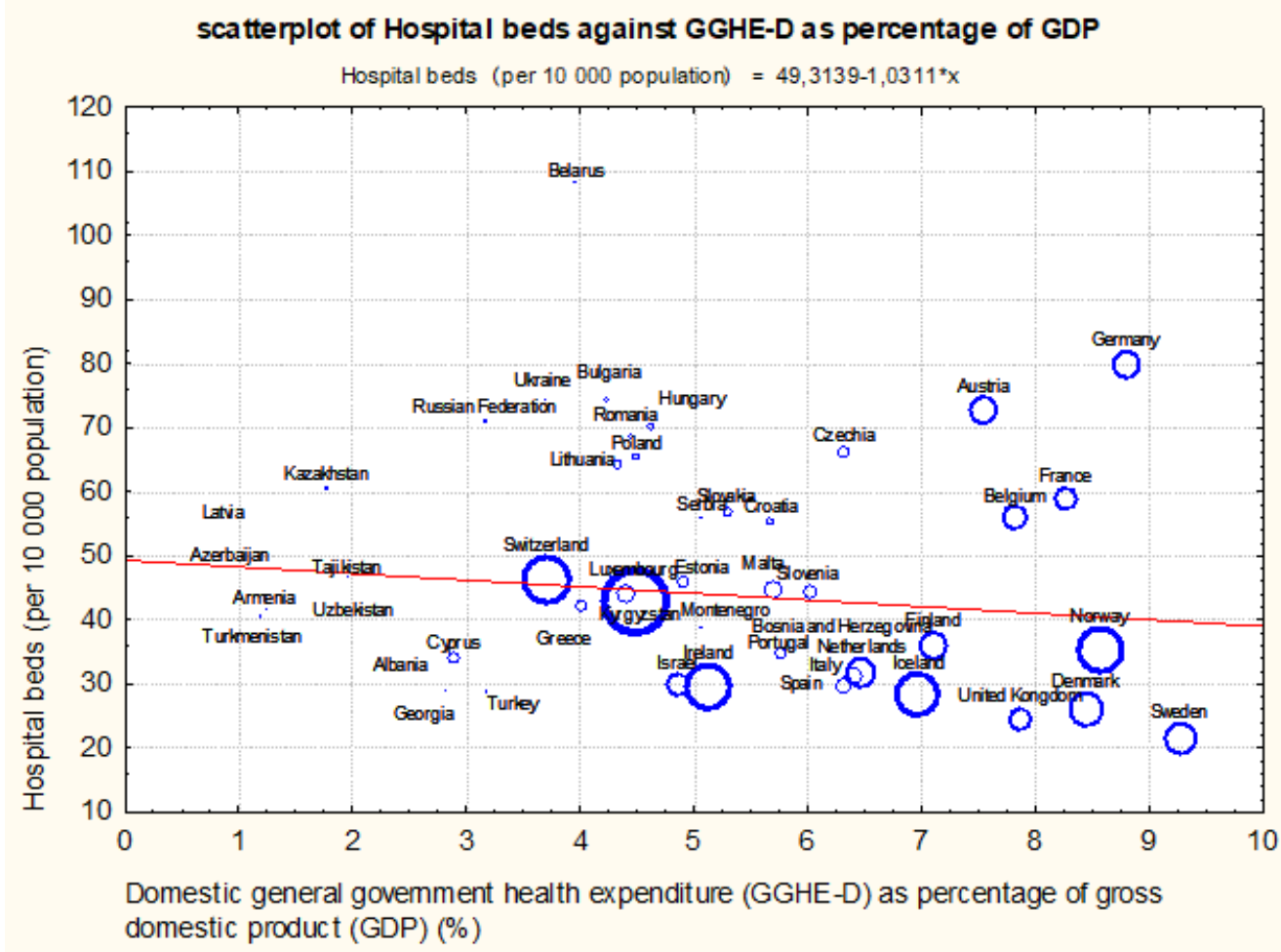

Fig. 3. Distribution of European and post-Soviet countries by the share of expenditures on the health care system and provisions of the population with hospital beds (constructed by $[9,52]$ )

countries is in Belarus and it is 108 beds / 10,000 population. More than 55 beds / 10,000 population are in Serbia, Republic of Moldova, Slovakia, Kazakhstan, Lithuania, Poland, Czechia, Romania,
Hungary, Russian Federation, Bulgaria. Regarding the statistical indicators of Ukraine, the population provision with hospital beds is 74,6 hospital beds per 10000 population. 
Compared to other countries, public spending on health care in Ukraine has been remained low. In 2014 , it decreased to $2.9 \%$, which is significantly below the average indicator for the European region's countries - 5\%, the European Union - 6\% and slightly below the average for countries with income levels below the average $-3.1 \%$. Thus, the share of domestic total government expenditures on health care in Ukraine's GDP is 3.7\%, 110 US dollars per population; population provision with doctors is 30 medical doctors per 10,000 population [3].

The health expenditures in Ukraine increased in real terms per capita by $20 \%$ between 2015 and 2020 , but this increase is partly due to a decrease in population (by $2.9 \%$ over the period) and it is much slower than economic growth. In addition, consolidated health expenditure as a percentage of GDP declined significantly by almost $15 \%$, indicating that public health expenditure grew much more slowly than the economy [1]. The decline in public expenditures on health care in Ukraine and the further increase in household payments are due to the conflicts, political instability and a sharp economic downturn in 2014 and 2015, insufficient resource provision, which was especially appeared in the conditions of global pandemic. The health workers' wages, particularly those working in the public finance sector, remain extremely low. Problems with COVID-19 are rapidly exacerbated in Ukraine, testing health care system.

By the time COVID-19 appeared, the situation had worsened and all the problems that have been growing since 1991 have worsened catastrophically. It turned out that medical institutions in Ukraine are not ready to fight epidemics. But the main problem was the lack of infectious disease doctors and the need for urgent retraining of doctors working in Ukraine, as the number of them has decreased significantly due to the significant emigration of highly qualified specialists.

During the year of the COVID-19 epidemic, a lot has been done in this direction, but the recovery process is slow. Thanks to patrons and charitable organizations, during this time many high-quality hospital equipment were created, oxygen was supplied and ventilators were purchased. But these "achievements" have paid a heavy price for the loss of many people's health and lives, including medical workers. There is no longer any doubt that no country in the world is able to overcome COVID-19 on its own, so the issue of immunization is becoming extremely important and urgent. Unfortunately, in this regard, Ukraine lags far behind many developed countries and Europe. Compared to many European countries, the vaccine arrived in Ukraine with a significant delay, only in the second half of February 2021, in a rather limited quantity and only one man- ufacturer (India). To date, there has been a situation of distrust to this vaccine and public fear of it. At the same time, there is a significant increase in the morbidity, which was somewhat restrained by previous quarantine measures, introduced in 2020 and early 2021. The third wave of COVID-19 is unfolding in Ukraine against the backdrop of these problems. Of course, Ukraine alone cannot get out of this critical situation without the support and assistance of the developed countries and Europe.

Overall, Ukraine has a wide range of problems in the health care system development, which are due to domestic problems and are complicated by the deployment of the global pandemic COVID-19. Let's identify current problems, prospects, opportunities and threats with the help of SWOT-analysis (table 1).

Conclusions. This study examines the health care system transformation using a human-geographical approach to the socio-geographical processes. The 21 st century poses a number of serious challenges to the global community that require a concerted effort by all world countries. This is especially true of the emergence and spread of new dangerous diseases that threaten the world's population in the form of global pandemics. This is clear from the analysis of these problems on the example of Ukraine, which, like other countries in this group, needs the support and assistance of other more successful countries in socio-economic terms. The health care system plays an exceptional role in the structure of the social sphere of each state. However, in the last few years, in connection with the global COVID-19 pandemic, new requirements regarding the level and quality of medical care have been put forward in Ukraine and internationally. It is significant that even the health care systems of highly developed countries at the height of the pandemic were on the verge of collapse and the health care system of Ukraine has shown once again its inability to provide quality medical services. Thus, it is urgent to study current trends in world medical practice, effective models of health care systems in different countries and the possibilities of their implementation in Ukraine. Using human-geographical analysis of the state of the health care system of Ukraine, this study made the following observations regarding the country's ability to response to modern health-related challenges.

The analysis of a significant number of foreign and domestic scientific works showed that the development and improvement of the health care system is the subject of research by specialists in the medical field, economic, political, legal, geographical and many others. The research pays special attention to the issues of overcoming the "coronavirus" crisis, best health practices that can be used 
SWOT-analysis of the health care system development of Ukraine (summarized by the authors according to $[1,2,4,7,11,13,37,38,39,43,50]$ )

\begin{tabular}{|l|}
\hline \multicolumn{1}{|c|}{ Strengths } \\
\hline 1. Ukraine is one of the European countries with the \\
largest number of medical institutions and medical \\
specialists.
\end{tabular}

2. Sustainability of the main elements of the health care system of Ukraine, formed by the Semashko's system, which guaranteed its significant subsidies, possibility of access to medical services throughout the country.

3. Formation of the financing system of medical institutions depending on the volume of medical services provided by them to the population.

4. The ongoing reform of the medical field has allowed patients choosing a doctor according to their own preferences, regardless of registration, which is quite relevant at the moment, as there is a large cohort of people working or studying outside the place of registration.

5. Increasing the level of market capitalization and the volume of insurance operations, in particular, global companies that have offices in Ukraine are implementing the practice of health insurance of their employees.

6. Medical education in Ukraine is popular both in the country and abroad, as evidenced by the large number of foreign students studying medical specialties.

7. Interest of the world investors.

8. The "Affordable Medicines" program, which operates for elderly patients with chronic diseases, in particular - the cardiovascular system.

9. A significant number of hospitals, high availability of beds in terms of population in Ukraine.

\section{OPPORTUNITIES}

1. Introduction of a state-guaranteed package of medical services.

2. Formation of a managed market of paid medical services, promotion of health care institutions of all forms of ownership, creation of conditions to meet the population's needs in medical services.

3. Evolution of the health care system in the process of addressing the current challenges of the COVID19 pandemic.

4. Digitization of the health care system, the use of innovative technologies in the services provision, such as: coordination of appointments and procedures, exchange of data on analisis results and involvement of patients in treatment, development of medical directories, register of medical services, diagnoses and procedures.

5. Formation of the necessary resource funds in health care focuses on the conditions of the uncertain economy, which is constantly changing. Increasing the autonomy of hospitals.
Weaknesses

1. Imperfection of the regulatory framework in the field of health care.

2. Lack of a clear policy for the development of the health care system.

2. Uncompetitiveness of the modern health care system on the world market, lack of comprehensive modernization of the material base.

3. Significant reduction in the quality of personnel in the health care system of Ukraine, which is manifested in the low competitiveness of graduates of higher medical educational institutions.

4. Fragmentation of the proposed reforms and their partial implementation, lack of processes for monitoring the results of implemented reforms.

5. Corruption and bureaucratization of this industry, inconsistency with world standards of service.

6. Insignificant sector of introduction of the insurance medicine, which slows down the health care system development in Ukraine.

7. Insolvency of the population to be treated at their own expense, high cost of quality medicines, lack of certain imported medicines in the country.

8. Collapse of some population support programs (in particular, free hemodialysis), etc.

9. The focus of government on addressing the needs of the medical sector, rather than meeting the medical needs of the population, the lack of comprehensive programs for the rehabilitation of the population.

\section{THREATS}

1. Political and economic instability in the country.

2. High inflation level, which significantly affects the cost of medical services and medicines.

3. Exacerbation of the situation with COVID-19 and stagnation of the health care system.

4. Lack of own patented and clinically tested vaccine from COVID-19, the necessary equipment and facilities for its production, which leads to dependence on other countries.

5. Low solvency of the population.

6. Distrust of the domestic health care system and the qualification level of medical staff.

7. High workload of family doctors (about 2 thousand people per doctor), which makes it impossible to provide quality diagnostic and consulting care, especially during a pandemic.

8. Lack of proper means of ensuring medical staff's life and health during the diagnosis and treatment COVID-19 leads to the dismissal of 
6. Adherence to a unified health care policy and comprehensive regulation of modern processes.

7. Interaction with consumers of medical services in order to improve the service level.

8. Formation of a highly professional cohort of doctors of the future, creation of the continuous professional development system of medical workers with mandatory independent certification.

9. Improving logistics and providing specialized medical equipment to health care facilities.

10. Formation of the public health system on the basis of relevant legislation. Reorientation from the system of treatment to the system of strengthening the population health, quality provision of health and recreational needs of the population at the regional and national levels. Introduction of a system of socioeconomic incentives for a healthy lifestyle, restriction of advertising of alcohol, tobacco and other substances harmful to health, etc.

11. Guaranteeing the quality, effectiveness and availability of medicines.

12. Development of a cluster health care system based on coordination of common interests of health care institutions, educational institutions, research organizations, medicines suppliers, state and business structures, as well as public structures taking care of these issues.

13. Creating more transparent working conditions and greater accountability in the field of health care.

14. Providing support, including financial, to vulnerable groups.

by post-Soviet camp countries and developing countries, namely: the use of a powerful monitoring system, identifying sources of funding, attracting investors, the possibility of structural changes in the health care system. A number of domestic studies were also analyzed, stating that the healthcare system's reform is an integral part of socio-economic transformations in Ukraine.

With the help of retrospective analysis, we havedescribed the features of the Ukraine's health care system, identified key principles of the M. O. Semashko's system, outlined its positive and negative features preserved to this day. Semashko's system worked well in the conditions of commandadministrative system of management of state structures, including health care, which was entirely public. Since independence (1991) the classical M.O. Semashko's system began to "slip" in Ukraine. There were a number of reasons for this. One of the main problems is the economic issues associated with the severance of "established" ties in the Soviet space, as many large enterprises did not survive, became bankrupt, turned into enterprises with huge debts, or were forced to reduce production and workers. The reformation of the health care system medical staff, increasing the morbidity among physicians.

9. Lack of the clear course and clear progress in the implementation of the reform, thus the old system is already destroyed, and the new has not yet formed, which in a global pandemic can become extremely dangerous and have irreversible catastrophic consequences

10. "Brain drain" - migration abroad of talented professionals for employment and permanent residence.

11.The focus of global research over the past few years on overcoming the problem of COVID-19, which to some extent inhibits the development of other research areas of the medical field.

12.Further orientation of the affluent population to treatment in foreign medical institutions due to the lack of some specialized types of medical services (in particular - organ transplantation).

13. Outdated transport infrastructure does not always allow paramedics to reach a patient in need of emergency care in a timely manner. of Ukraine has been taking place without taking into account all the positive aspects of the M.O. Semashko's system, which led to the departure of a significant number of medical workers to private practice. The basis for the formation of a modern health care system in Ukraine is the M.O. Semashko's system, which at one time allowed to provide free general medical care, provide disease prevention, care for social hygiene. Its main feature was the comprehensive coverage of the population with medical services, treatment of the most common diseases at that time. However, the situation changed dramatically with the transition from a command-administrative to a market economy, and the M.O. Semashko's system gradually lost its effectiveness. Thus, the reform introduced by the Government of Ukraine, launched in 2015, it is a natural reaction to the decline of the outdated health care system. The reform aims to increase the efficiency of the health care system in order to improve public access to quality health services.

Statistical analysis has shown that currently Ukraine has extremely low indicators of financing the medical system both in terms of the share of expenditures from GDP and the provision of the popu- 
lation with these expenditures. According to statistics from the WHO, the cost of medicine in the world amounted to $10 \%$ of global gross domestic product, in Ukraine - 3.7\%, and GDP per population was about 3 thousand US dollars, per capita expenditures were 110 US dollars in 2019. These indicators are extremely low in comparison with the leading European countries, for the most part they are similar to the indicators of the post-Soviet countries, which in the context of modern challenges are the most vulnerable due to economic turmoil.

Today the health care system in Ukraine is in a state of transformation. Insurance medicine is still in a rudimentary state and does not always meet the needs (financial in the first place) of the population. Salaries of physicians remain quite low compared to neighboring countries, which, in turn, leads to an increase in the "outflow" of health workers from the country. One of the most painful mistakes of the "transformation" of the health care system was the cessation of training of infectious diseases specialists in higher education institutions starting in 2019, as well as the reduction, consolidation and elimination of a number of specialized hospitals, infectious diseases hospitals, tuberculosis dispensaries, mental hospitals, etc. which immediately led to the outbreaks and a spread of such dangerous diseases as measles, tuberculosis, HIV, AIDS, etc. The number of beds in hospitals and the material and technical equipment of medical institutions have sharply decreased. Medical services became inaccessible to the general population, as economic problems in Ukraine grew and reached its apogee in 2014, when Russia's aggression against Ukraine began, then the annexation of the Autonomous Republic of Crimea and the implementation of joint forces operation in Donbas.
SWOT-analysis of the development of the Ukraine's health care system showed the presence of a wide range of strengths and weaknesses, opportunities and threats to development. Among the strengths it is worth noting the high supply of medical institutions and medical professionals, a quality basis for development - the M.O. Semashko's system, and attempts to implement global models of medical development. Among the weaknesses are the outdated material and technical base, insufficient level of funding and inefficient use of available resources of the health care system. Among the threats to the development are the aggravation of the situation with COVID-19, the lack of a clear course and clear progress in the implementation of the reform, so the old system is already destroyed, and the new one has not yet formed, which during the global pandemic can be extremely dangerous and have irreversible catastrophic consequences, labor migration of talented doctors. Among the opportunities are the creation of sufficient resources in the field of health care in an uncertain, changing economy, interaction with consumers of medical services to improve patient care, forming a highly qualified cohort of doctors of the future, improving logistics and providing specialized medical equipment health care system.

In further research, the authors are going to continue their analysis of the health care system of individual regions of Ukraine using humangeographical approach, to analyze and monitor the status of dangerous diseases, in particular at COVID-19 in the regions of Ukraine; to analyse institutional changes to strengthenthe state of the health care system in Ukraine as a whole in order to improve the quality and life expectancy of the population.

\section{Bibliography}

1. Бюджетний простір для системи охорони здоров'я в Україні. Програмний документ для підтримки діалогу щзодо підготовки бюджету на 2021 рік / Всесвітня організація охорони здоров'я. - 2020. - № 20/01. - 27 с. Режим достуny: https://www.euro.who.int/en/countries/ukraine/publications/budgetary-space-for-health-inukraine.-policy-document-to-support-budget-preparation-dialogue-for-20212020

2. Долбнєва Б. В. Необхідність та основні напрямки вдосконалення формування та використання ресурсного потенціалу охорони здоров'я в Україні / В. Д. Долбнєва, С. М. Гончарук // Економіка та управління національним господарством. Проблеми економіки. - 2016. - № 3. - C. 46-52. - Режим доступу: https://www.problecon.com/export_pdf/problems-of-economy-2016-3_0-pages-46_52.pdf

3. Кадрові ресурси системи охорони здоров'я в Украйні. Ситуаційний аналіз / Д. Богдан, А. Бойко, А. Василькова та ін. Проект USAID «Підтримка реформи охорони здоров'я». - Київ, 2019. - 133 с. - Режим доступу: https://www.skeptic.in.ua/wp-content/uploads/HRH-situational-analysis-2019.pdf

4. Корнійчук О. П. Трансформачія системи охорони здоров'я: стан та перспективи / О. П. Корнійчук // Український медичний часопис. Актуальні питання клінічної практики. - 2013. - № 4 (96) [Електронний ресурс]. Режим достуny: https://www.umj.com.ua/article/63259/transformaciya-sistemi-oxoroni-zdorov-ya-ukraini-stan-taperspektivi

5. Мельниченко А. 10 стран с лучшей системой здравоохранения в мире / A. Мельниченко // Благодійна організація «Лікарська каса Житомирськой області». - 9 жовтня, 2017 [Електронний ресурс]. - Режим доступу: https://likkasa.com.ua/10-stran-s-luchshej-sistemoj-zdravooxraneniya-v-mire/

6. Механик А. Пирамида Семашко / А. Механик // Эксперт. - 1 августа 2011 [Електронний ресурс]. - Режим docmyny: https://expert.ru/expert/2011/30/piramida-semashko/ 
7. Наџіональна стратегія реформування системи охорони здоровя в Ураӥні на період 2015-2020. - 41 с. [Електронний ресурс]. Режим доступу: https://uoz.cn.ua/strategiya.pdf

8. Нємецьь К. А. Багатовимірний аналіз у суспільній географї (нетрадиційні методи). Монографія / К. А. Нємець, К. Ю. Сегіда, Л. М. Немець. - Харків: Харківський наџіональний університет імені В. Н. Каразіна, 2016. $-120 \mathrm{c}$.

9. Офіиіийнй веб-сайт Світової організації охорони здоров'я [Електронний ресурс]. - Режим доступу: https://www.who.int/data/gho/data/indicators

10. Пандемія довела: у медичних вишах України відновлять навчання вірусологів / Новинарня. - 13 травня 2020 [Електронний ресурс]. - Режим доступy: https://novynarnia.com/2020/05/13/virusolohy/

11. Правові засади реформування галузі охорони здоров'я : стан, проблеми, перспективи розвитку / Міністерство юстииї [Електронний ресурс]. - Режим доступу: https://minjust.gov.ua/m/str_6764

12. Про державні фінансові гарантії медичного обслуговування населення / Відомості Верховної Ради. - 2018. № 5, cm. 31 [Електронний ресурс]. - Режим достуny: https://zakon.rada.gov.ua/laws/show/2168-19\#Text

13. Сазонець І. Л. Визначення проблем та основних напрямів реформування системи охорони здоров'я Украӥни / І. Л. Сазонець, І. Я. Зима // Електронний журнал «Державне управління: удосконалення та розвиток». 2018. - № 12. DOI: https://doi.org/10.32702/2307-2156-2018.12.2

14. Тогрун О. Чотири моделі страхової медицини. Яку обрала нова влада? / О. Торгун // НМ. - 24 січня 2020 [Електронний ресурс] - Режим достуnу: https://nv.ua/opinion/strahovaya-medicina-v-ukraine-chto-stoit-znatposlednie-novosti-50065848.html

15. Atun R. Transforming Turkey's Health System / R. Atun // The New England Journal of Medicine. - 2015. - 373 (14). - P. 1285-1289. DOI: https://doi.org/10.1056/NEJMp1410433

16. Bertens R.M. Small steps, big change. Forging a public-private health insurance system in the Netherlands / R.M. Bertens, R. A. A. Vonk // Social Science \& Medicine. - 2020. - Vol. 266. - 113418. DOI: https://doi.org/10.1016/j.socscimed.2020.113418

17. China's Progress Report on Implementation of the 2030 Agenda for Sustainable Development (2019) / Ministry of Foreign Affairs of the People's Republic of China. - Semtember, 2019. - 122. c. - Режим доступy: https://www.fmprc.gov.cn/mfa eng/topics_665678/2030kcxfzyc/P020190924780823323749.pdf

18. Cockerham W.C. Health lifestyles and political ideology in Belarus, Russia, and Ukraine / W.C. Cockerham, B.P. Hinote, G.B.Cockerham, P. Abbott // Social Science \& Medicine - 2006. - Vol. 62 (Issue 7). - P. 1799-1809. DOI: https://doi.org/10.1016/j.socscimed.2005.08.024

19. Cybulska A. Korzystanie ze świadczeń i ubezpieczeń zdrowotnych / A. Cybulska // KOMUNIKATzBADAŃ . - 2016. NR 112. - 17 p. - Режuм docmyny: https://www.cbos.pl/SPISKOM.POL/2016/K_112_16.PDF

20. Dózsa C. Structural Changes in the Hungarian Healthcare System Between 2000 and 2017 / C. Dózsa, K. Jankus, T.M. Helter // Value in Health Regional. - 2019. - Issues, 19. - P. 92-98. DOI: https://doi.org/10.1016/j.vhri.2019.05.002

21. Gheorghita E. Bugetul Ministerului Sănătăţii, mai mare cu 80,95\% în 2013 / E. Gheorghita // Mediafax.ro. - 2013, January 21. - Режим достуny: https://www.mediafax.ro/economic/bugetul-ministerului-sanatatii-mai-mare-cu-8095-in-2013-10511758

22. Inoue S. Construction of System Dynamics Model for Medical Care System of Japan / S. Inoue, H. Xu., J. Maswana, M. Kobayashi // Value in Health. - 2016. - 19 (7). - P. A820. DOI: https://doi.org/10.1016/j.jval.2016.08.616

23. Kerner A. Description Of The Chinese Health Care System After The Health Care Reform / Á. Kerner, T. Csákvári, J. Betlehem, B. Molics, N. Danku, D. Endrei et al. // Value in Health. - 2017. - 20 (9). - P. A514. DOI: https://doi.org/10.1016/j.jval.2017.08.652

24. Kostrikov S. Geoinformation Approach to Urban Geographic System Research (Case Studies of Kharkiv region, Ukraine) / S. Kostrikov, L. Niemets, K. Sehida, K. Niemets, C. Morar // Visnyk of V. N. Karazin Kharkiv National University, series "Geology. Geography. Ecology", 2018. - Issue 49. - P. 107-124. DOI: https://doi.org/10.26565/2410-7360-2018-49-09

25. Lanea J. Strengthening health policy development and management systems in low-and middle-income countries: South Africa's approach / Lanea, J., Andrews, G., Orange, E., Brezak, A., Tanna, G., Lebese, L., et al. // Health Policy OPEN. - 2020. - Vol. 1. - 100010. DOI: https://doi.org/10.1016/j.hpopen.2020.100010

26. Lekhan V. Ukraine. Health system review / V. Lekhan, V. Rudiy, E. Richardson // Health Systems in Transition. 2010. - 12 (8):1. - P. 183. Режим docmyny: https://www.euro.who.int/_data/assets/pdf file/0011/152849/ e94973R.pdf

27. Liu Y. China's Health Care Reform: Far From Sufficient / Y. Liu. - The New York Times. - 2011, November 1. Режим достуny: https://www.nytimes.com/roomfordebate/2011/11/01/is-china-facing-a-health-care-crisis/chinashealth-care-reform-far-from-sufficient

28. Luck J. Patient and provider perspectives on quality and health system Patient and provider perspectives on quality and health system effectiveness in a transition economy: Evidence from Ukraine / J. Luck, J.W. Peabody, L.M. DeMaria, C.S.Alvarado, R. Menon // Social Science \& Medicine. - 2014. - Vol. 114. - P. 57-65. DOI: https://doi.org/10.1016/j.socscimed.2014.05.034

29. Lukić T. Rainfall erosivity and extreme precipitation in the Pannonian Basin - preliminary results / T. Lukić, A. Lukić, B. Basarin, T. Ponjiger, D. Blagojević, M. Mesaroš, M. Milanović, M.Gavrilov, D. Pavić, M. Zorn, B. Komac, 
Đ. Miljković, D. Sakulski, S. Babić-Kekez, C.Morar, S. Janićević // Open Geosciences. - 2019. - Vol. 11(1). - P. 664681. DOI: https://doi.org/10.1515/geo-2019-0053

30. McMahon J. 5 Facts about healthcare in Romania / J. McMahon // The Borgen Project. - 2020, August 5. - Peжuм docmyny: $\quad$ https://borgenproject.org/healthcare-in-romania/\#: : text=Romania\%20has $\% 20 a \% 20$ program $\% 20$ of\% 20universal $\% 20$ health $\% 20$ insurance.\&text $=$ Romania $\% 20$ consistently $\% 20$ spends $\% 20$ around $\% 204$, are $\% 20$ aging $\% 2$ Oand\%20chronically\%20underfunded

31. Mehtap T. The Health Insurance System in Turkey / T. Mehtap, S. Mollahalilog lu // Angluinfo Turkey. - 2011 [Електронний ресурс]. - Режим достуny: https://www.angloinfo.com/how-to/turkey/healthcare/healthsystem/health-insurance

32. Memia F. Health Care Insurance System in the Republic of Albania and Development Perspective / F. Memia // Journal of Educational and Social Research. - 2015. - Vol. 5, №1. - P. 49-53. DOI: https://doi.org/10.5901/jesr.2015.v5n1p49

33. Morar C. Aspects Regarding the Military Cultural-Historical Heritage in the City of Oradea, Romania / C. Morar, G. Nagy, M. Dulca, L. Boros and K. Sehida //ANNALES - Annals for Istrian and Mediterranean Studies - Series Historia et Sociologia. - 2019. - Vol. 29, Issue 2. - P. 303-323. - Режим доступy: https://www.researchgate.net/publication/336720560_Aspects_regarding the military_cultural-historical heritage in the city of Oradea Romania

34. Morar C. Brownfields Regeneration, between Sustainable Urban Development and Cultural Heritage, the former military sites in Oradea, Romania / C. Morar, M. Dulca, G. Nagy // Journal of Urban and Regional Analysis. 2016. - Vol. VIII (1). - P. 75-84. DOI: https://doi.org/10.37043/JURA.2016.8.1.6

35. Morar C.Shaping Sustainable Urban Environments by Addressing the Hydro-Meteorological Factors in Landslide Occurrence: Ciuperca Hill (Oradea, Romania) / C. Morar, T. Lukić, B.Basarin, A. Valjarević, M. Vujičić, L. Niemets, I. Telebienieva, L. Boros, G. Nagy // International Journal of Environmental Research and Public Health. - 2021. Vol. 18(9). - 5022. DOI: https://doi.org/10.3390/ijerph18095022

36. Morar C.Heritage, Culture and Regeneration of the former Military Areas in the city of Oradea (Romania) / C. Morar, G. Nagy, L. Boros, M. Gozner, L. Niemets, K. Sehida // Architektúra \& urbanizmus. - 2021. - Vol. 55. - P. 1-2.

37. Nemets L. Analysis of development trajectory for social infrastructure of Kharkiv region / L. Nemets, P. Kobylin, K. Segida // Actual Problems of Economics. - 2014. - 161 (11). - P. 409-418.

38. Niemets K. Features of social and geographical researches of health care system of the border region / K. Niemets, L. Kliuchko, G. Kulieshova // Economic Annals-XXI. - 2015. - №1-2 (1). - P. 93-97. Режим достуny: http://nbuv.gov.ua/UJRN/ecchado 2015 1-2(1) 24

39. Niemets K. Some Issues of the Formation and Implementation of the Development Strategies of Ukraine's Regions Taking into Account European Experience / K. Niemets, K. Sehida, L. Niemets, O. Krainyukov, I. Telebienieva, P. Kobylin // Proceedings of the 32nd International Business Information Management Association Conference (2018, November 15-16, Seville, Spain,). - P. 314-327 [Електронний ресурс]. - Режим доступу: https://ibima.org/accepted-paper/formation-and-implementation-of-the-development-strategies-of-ukraines-regionsin-the-aspect-of-eurointegration/

40. Niemets $K$. The analysis of the research results of sociogeographical features of Donetsk region's social development as an old industrial region / K. Niemets, J. Yakovleva, L. Niemets // Actual Problems of Economics. - 2014. 162 (12). - P. 271-280.

41. Niemets L. Innovation and Investment Potential of Region as a Factor of its” Smart Transformation": Kharkiv Region Case Study (Ukraine) / L. Niemets, K. Mezentsev, C. Morar, K. Sehida, N. Husieva, V. Peresadko // Visnyk of V. N. Karazin Kharkiv National University, series "Geology. Geography. Ecology", 2018. - Issue 49. - P. 137-159. DOI: https://doi.org/10.26565/2410-7360-2018-49-11

42. Popchenko, T. On the priority areas for improving the domestic health sector. Analytical note / T. Popchenko // National Institute for Strategic Studies [Електронний ресурс]. - Режим доступу: http://old2.niss.gov.ua/articles/480/

43. Quantitative and qualitative analysis of Ukraine's emergency medical services to assess current capacities and opportunities for future development (2020)/World Health Organization. Regional Office for Еигоре [Електронний pecypc]. - Режим достуny: https://www.euro.who.int/en/countries/ukraine/publications/quantitative-andqualitative-analysis-of-ukraines-emergency-medical-services-to-assess-current-capacities-and-opportunities-forfuture-development-2020

44. Sheiman I. Rocky road from the Semashko to a new health model / I. Sheiman // Bull World Health Organ. - 2013. 91. - P. 320-321. DOI: http://dx.doi.org/10.2471/BLT.13.030513

45. Slaybaugh C. (n.d.). International Healthcare Systems: The US Versus the World / C. Slaybaugh (n.d.) // Axene Health Partners [Електронний ресурс]. - Режим доступy: https://axenehp.com/international-healthcare-systemsus-versus-world/

46. Stankov U.Shared Aerial Drone Videos - Prospects and Problems for Volunteered Geographic Information Research / U. Stankov, Đ. Vasiljević, V. Jovanović, M. Kranjac, M.Vujičić, C. Morar, L. Bucur // Open Geosciences. 2019. - Vol. 11(1). - P. 462-470. DOI: https://doi.org/10.1515/geo-2019-0037

47. Tomini S. M. Paying out-of-pocket and informally for health care in Albania: the impoverishing effect on households / S. M. Tomini, W. Groot, M. Pavlova, F.Tomini // Frontiers in Public Health. - 2015. DOI: https://doi.org/10.3389/fpubh.2015.00207 
48. TOP 10: Countries with the best healthcare system [Електронний ресурс]. - Режим доступу: https://www.cignaglobal.com/blog/healthcare/top-10-countries-best-healthcare-system

49. Tran L.D. Public health and the economy could be served by reallocating medical expenditures to social programs $/$ L.D. Tran, F.J. Zimmerman, J.E. Fielding // SSM - Population Health. - 2017. - Vol. 3. - P. 185-191. DOI: https://doi.org/10.1016/j.ssmph.2017.01.004

50. Ukraine: review of health financing reforms 2016-2019 / WHO-World Bank Joint Report, 2019 [Електронний pecypc]. - Режим достуny: https://www.euro.who.int/_data/assets/pdf file/0018/425340/WHO-WB-JointReport_UKR_Full-report_Web.pdf

51. Vujičić D. M. A multi-criteria decision analysis with special reference to loess and archaeological sites in Serbia (Could geosciences and archaeology cohabitate?) / D. M. Vujičić, D. A. Vasiljević, T.A. Hose, N. Tasić, C. Morar, A.Đurić, S. B. Marković // Open Geosciences. - 2018. - Vol. 10 (1). - P.333-343. DOI: https://doi.org/10.1515/geo2018-0026

52. World Bank national accounts data, and OECD National Accounts data files. [Електронний ресурс]. - Pежим docmyny: https://data.worldbank.org/indicator/NY.GDP.MKTP.CD?view $=$ chart

53. Xiao Y. Towards healthy China 2030: Modeling health care accessibility with patient referral / Y. Xiao, X.Chen, Q. Li, P. Jia, L. Li, Z. Chen // Social Science \& Medicine. - 2021. - Vol. 276. - P. 113834. DOI: https://doi.org/10.1016/j.socscimed.2021.113834

Submitted April 7, 2021

Accepted May 17, 2021

Authors Contribution: All authors have contributed equally to this work.

UDC 911.3:614(477)

Liudmyla Niemets,

DSc (Geography), Professor, Head of the Department of Human Geography and Regional Studies, V.N. Karazin Kharkiv National University, 4 Svobody Sq., Kharkiv, 61022, Ukraine, e-mail: ludmila.nemets@karazin.ua, https://orcid.org/0000-0001-9943-384X;

\section{Oksana Bartosh,}

Associate Faculty, School of Humanitarian Studies, Environment, Sustainability, Royal Roads University, 2005 Sooke Road, Victoria BC V9B 5Y2, Canada, e-mail: obartosh@directions-eprg.ca;

Kateryna Sehida,

DSc (Geography), Associate Professor, Department of Human Geography and Regional Studies,

V.N. Karazin Kharkiv National University, e-mail: kateryna.sehida@karazin.ua,https://orcid.org/0000-0002-1122-8460;

Kostiantyn Niemets,

DSc (Geography), Professor, Department of Human Geography and Regional Studies,

V.N. Karazin Kharkiv National University, e-mail: konnem1948@gmail.com, https://orcid.org/0000-0002-7262-2111;

\section{Liudmyla Kliuchko,}

$\mathrm{PhD}$ (Geography), Associate Professor, Department of Human Geography and Regional Studies,

V.N. Karazin Kharkiv National University, e-mail: ludmila.klychko@karazin.ua, https://orcid.org/0000-0001-6937-3364;

\section{Kateryna Kravchenko,}

$\mathrm{PhD}$ (Geography), Associate Professor, Department of Human Geography and Regional Studies,

V.N. Karazin Kharkiv National University, e-mail: kateryna.kravchenko@karazin.ua, https://orcid.org/0000-0003-4654-3185;

Ievgeniia Telebienieva,

$\mathrm{PhD}$ (Geography), Associate Professor, Department of Human Geography and Regional Studies,

V.N. Karazin Kharkiv National University,

e-mail: telebenevaev@gmail.com, http://orcid.org/0000-0002-7013-8836

\section{HUMAN-GEOGRAPHICAL PECULIARITIES OF THE HEALTHCARE SYSTEM OF UKRAINE IN THE CONDITIONS OF MODERN CHALLENGES}

Relevance. The paper examines the issues of the health care system development of Ukraine in the context of modern challenges. Today, there are many global environmental, socio-demographic, and economic problems threatening the existence of human civilization. One of the problems was the spread of coronavirus infection COVID-19, which demonstrated unpreparedness of Ukraine and post-socialist countries' health 
care systems. These countries are undergoing health care transformations, but they do not meet modern world norms and standards.

The purpose of the article is to establish the key features of the health care system of Ukraine during its transformation given the positive experience of medical systems in the world, from the positions of human geography to identify current challenges and to assess the ability to respond to social demand and the threat of the global crisis in the form of new diseases, the spread of epidemics threatening to human health, quality and life expectancy.

Methods. This research is conducted on the basis of human-geographical approach with use of the set of methods and tools to analyze the health care system, which is extremely important for obtaining verified and scientifically sound results. In particular, the authors used methods of induction and deduction, comparison, formalization, analogy, analysis, systematization, including ranking and grouping, historical, graphical, mathematical and statistical, SWOT-analysis methods.

Results. Scientific novelty and practical significance. The features, advantages and disadvantages of existing models of health care systems in different countries were identified. In particular, models of medical systems were considered: a model of the single-payer, model of obligatory insurance, and hybrid system. The peculiarities of the formation of the health care system of Ukraine were determined, the key features and principles of the M.O. Semashko's system were identified, its positive and negative features preserved to this day were outlined. The distribution of European and post-socialist countries was analyzed according to the indicators of state budget expenditures on health care and GDP, number of doctors, hospital beds per capita. The transformational processes in the health care system of Ukraine, the peculiarities of the medical reform in Ukraine were revealed, the peculiarities of the development of the medical system in the conditions of the pandemic were characterized. The SWOT analysis identified the strengths and weaknesses of the Ukraine's health care system in terms of reform and transformation, its opportunities and threats in the light of current challenges.

Keywords: health care system, insurance medicine, World Health Organization, GDP per capita, Ukraine, post-socialist countries.

\section{References}

1. Budgetary space for health in Ukraine. Policy document to support budget preparation dialogue for 2021 (2020). Health Policy Paper Series No. 20/01. World Health Organization. Regional Office for Europe. Available at: https://www.euro.who.int/en/countries/ukraine/publications/budgetary-space-for-health-in-ukraine.-policydocument-to-support-budget-preparation-dialogue-for-20212020 [in Ukrainian].

2. Dolbneva, D.V., Goncharuk, S.M. (2016). Neobkhidnist ta osnovni napriamky vdoskonalennia poriadku formuvannia ta vykorystannia resursnoho potentsialu okhorony zdorovia $v$ Ukraini. [The necessity and main directions for improving the order of the formation and use of resource potential of health care in Ukraine]. Ekonomika ta upravlinnia natsionalnym hospodarstvom, Problemy ekonomiky [Economics and management of the national economy, Problems of economy], 3, 46-52. Available at: https://www.problecon.com/export pdf/problems-of-economy-20163 0-pages-46_52.pdff [in Ukrainian].

3. Bogdan, D., Boyko, A., Vasilkova, A. et al. (2019). Kadrovi resursy systemy okhorony zdorovia v Ukraini. Sytuatsiinyi analiz. Proekt USAID «Pidtrymka reformy okhorony zdorovia» [Human resources of the health care system in Ukraine. Situational analysis. USAID Health Care Reform Support Project]. Kiev. Available at: https://www.skeptic.in.ua/wp-content/uploads/HRH-situational-analysis-2019.pdf [in Ukrainian].

4. Korniychuk, O.P. (2013). Transformatsiia systemy okhorony zdorovia Ukrainy: stan ta perspektyvy [Health care transformation in Ukraine: the state and prospects]. Ukrainskyi medychnyi chasopys. Aktualni pytannia medychnoi praktyky [Ukrainian medical journal. Current issues of medical practice], 4 (96), VII/VIII. Available at: https://www.umj.com.ua/article/63259/transformaciya-sistemi-oxoroni-zdorov-ya-ukraini-stan-ta-perspektivi [in Ukrainian].

5. Melnichenko, A. (2017, October 9). 10 stran s luchshej sistemoj zdravoohranenija v mire [10 Countries with the best healthcare system in the world] Available at: https://likkasa.com.ua/10-stran-s-luchshej-sistemoj-zdravooxraneniyav-mirel [in Russian].

6. Mechanic, A. (2011, August 1).Pyramyda Semashko [Semashko's Pyramid]. Expert, $30-31$ (764). Available at: https://expert.ru/expert/2011/30/piramida-semashko// [in Russian].

7. Natsionalna stratehiia reformuvannia systemy okhorony zdorovia v Ukraini na period 2015-2020 roky [National strategy for reforming the health care system in Ukraine for the period 2015-2020]. Available at: https://uoz.cn.ua/strategiya.pdf [in Ukrainian].

8. Niemets, K. A., Sehida, K. Yu., Niemets, L. M. (2016). Multidimensional analysis in human geography (nontraditional methods): monograph [Bahatovymirnyy analiz u suspil'niy heohrafiyi (netradytsiyni metody): monohrafiya], Kharkiv, V.N. Karazin Khrakiv National University, 120 [in Ukrainian].

9. Official web-site of the World Health Organization. Available at: https://www.who.int/data/gho/data/indicators 
10. Pandemiia dovela: $u$ medychnykh vyshakh Ukrainy vidnovliat navchannia virusolohiv [The pandemic proved: training of virologists will be resumed in medical universities of Ukraine] (2020, May 13). Novynarnia. Available at: https://novynarnia.com/2020/05/13/virusolohy/ [in Ukrainian].

11. Pravovi zasady reformuvannia haluzi okhorony zdorovia: stan, problemy, perspektyvy rozvytku [Legal bases of health care reform: state, problems, prospects of development]. Available at: https://minjust.gov.ua/m/str 6764 [in Ukrainian].

12. Pro derzhavni finansovi harantii medychnoho obsluhovuvannia naselennia [About the state financial guarantees of medical service of the population] 2168-VIII. Vidomosti Verkhovnoi Rady [Information of the Verkhovna Rada], № 5, art.31 (2018) [in Ukrainian].

13. Sazonets, I., Zyma, I. (2018). Identification of problems and main directions of reform health care system of Ukraine. Elektronnyi zhurnal «Derzhavne upravlinnia: udoskonalennia ta rozvytok» [Electronic journal "Public Administration: Improvement and Development"], 12, https://doi.org/10.32702/2307-2156-2018.12.2

14. Torhun, A. (2020, January 24). Four models of health insurance. Which one did the new government choose? NV. Available at: https://nv.ua/opinion/strahovaya-medicina-v-ukraine-chto-stoit-znat-poslednie-novosti-50065848.html

15. Atun, R. (2015, October 1,). Transforming Turkey's hHealth Ssystem. The New England Journal of Medicine, 373 (14), 1285-1289, https://doi.org/10.1056/NEJMp1410433

16. Bertens, R.M., Vonk, R.A.A. (2020). Small steps, big change. Forging a public-private health insurance system in the Netherlands. Social Science \& Medicine, 266, 113418, https://doi.org/10.1016/j.socscimed.2020.113418

17. China's Progress Report on Implementation of the 2030 Agenda for Sustainable Development (2019): Ministry of Foreign Aff airs of the People's Republic of China. Available at: https://www.fmprc.gov.cn/mfa_eng/topics_665678/2030kcxfzyc/P020190924780823323749.pdf

18. Cockerham, W.C., Hinote, B.P., Cockerham, G.B., Abbott, P. (2006). Health lifestyles and political ideology in Belarus, Russia, and Ukraine. Social Science \& Medicine, 62 (7), 1799-1809, https://doi.org/10.1016/j.socscimed.2005.08.024

19. Cybulska, A. (2016). Korzystanie ze świadczeń i ubezpieczeń zdrowotnych. KOMUNIKATzBADAŃ, NR 112. Available at: https://www.cbos.pl/SPISKOM.POL/2016/K 112 16.PDF

20. Dózsa, C., Jankus, K., Helter, T.M. (2019). Structural Changes in the Hungarian Healthcare System Between 2000 and 2017. Value in Health Regional Issues, 19, 92-98. https://doi.org/10.1016/j.vhri.2019.05.002.

21. Gheorghita, E. (2013, January 21). Bugetul Ministerului Sănătăţii, mai mare cu 80,95\% în 2013. Mediafax.ro. Available at: https://www.mediafax.ro/economic/bugetul-ministerului-sanatatii-mai-mare-cu-80-95-in-201310511758

22. Inoue, S., Xu. H., Maswana, J., Kobayashi, M. (2016). Construction of System Dynamics Model for Medical Care System of Japan. Value in Health, 19 (7), A820, https://doi.org/10.1016/j.jval.2016.08.616

23. Kerner, Á., Csákvári, T., Betlehem, J., Molics, B., Danku, N., Endrei, D et al. (2017). Description Of The Chinese Health Care System After The Health Care Reform. Value in Health, 20 (9), A514, https://doi.org/10.1016/j.jval.2017.08.652

24. Kostrikov, S., Niemets, L., Sehida, K., Niemets, K., Morar, C. (2018). Geoinformation Approach to Urban Geographic System Research (Case Studies of Kharkiv region, Ukraine). Visnyk of V. N. Karazin Kharkiv National University, series "Geology. Geography. Ecology", 49, 107-124, https://doi.org/10.26565/2410-7360-2018-49-09

25. Lanea, J., Andrews, G., Orange, E., Brezak, A., Tanna, G., Lebese, L., et al. (2020). Strengthening health policy development and management systems in low-and middle-income countries: South Africa's approach. Health Policy OPEN, 1, 100010, https://doi.org/10.1016/j.hpopen.2020.100010

26. Lekhan, V., Rudiy, V., Richardson, E. (2010). Ukraine. Health system review. Health Systems in Transition, 12 (8). https://www.euro.who.int/ data/assets/pdf file/0011/152849/e94973R.pdf

27. Liu, Y. (2011, November 1). China's Health Care Reform: Far From Sufficient. The New York Times. Available at: https://www.nytimes.com/roomfordebate/2011/11/01/is-china-facing-a-health-care-crisis/chinas-health-care-reformfar-from-sufficient

28. Lucka, J., Peabodybc, J.W., DeMariabc, L.M., Alvaradoa, C.S., Menond, R. (2014). Patient and provider perspectives on quality and health system Luck, J., Peabody, J.W., DeMaria, L.M., Alvarado, C.S., Menon, R. (2014). Patient and provider perspectives on quality and health system effectiveness in a transition economy: Evidence from Ukraine. Social Science \& Medicine, 114, August 2014, 57-65, https://doi.org/10.1016/j.socscimed.2014.05.034

29. Lukić, T., Lukić, A., Basarin, B., Ponjiger, T., Blagojević, D., Mesaroš, M., Milanović, M., Gavrilov, M., Pavić, D., Zorn, M., Komac, B., Miljković, Đ., Sakulski, D., Babić-Kekez, S., Morar, C. \& Janićević, S. (2019). Rainfall erosivity and extreme precipitation in the Pannonian Basin - preliminary results. Open Geosciences, 11(1), 664-681, https://doi.org/10.1515/geo-2019-0053

30. McMahon, J. (2020, August 5). 5 Facts about healthcare in Romania. The Borgen Project. Available at: https://borgenproject.org/healthcare-in-romania/\#: : text=Romania\%20has\%20a\%20program\%20of\% 20universal\%20health\%20insurance. \& text $=$ Romania\%20consistently $\% 20$ spends $\% 20$ around $\% 204$,are $\% 20$ aging $\% 2$ Oand\%20chronically\%20underfunded

31. Mehtap, T., Mollahalilog `u, S. (2011). The Health Insurance System in Turkey. Angluinfo Turkey. Available at: https://www.angloinfo.com/how-to/turkey/healthcare/health-system/health-insurance

32. Memia, F. (2015). Health Care Insurance System in the Republic of Albania and Development Perspective. Journal of Educational and Social Research, 5 (1), January 2015. https://doi.org/10.5901/jesr.2015.v5n1p49 
33. Morar, C., Dulca, M., Nagy, G. (2016). Brownfields Regeneration, between Sustainable Urban Development and Cultural Heritage, the former military sites in Oradea, Romania. Journal of Urban and Regional Analysis, VIII (1), 75-84, https://doi.org/10.37043 / JURA.2016.8.1.6

34. Morar, C., Nagy, G., Dulca, M., Boros, L., Sehida, K. (2019). Aspects Regarding the Military Cultural-Historical Heritage in the City of Oradea, Romania. ANNALES - Annals for Istrian and Mediterranean Studies - Series Historia et Sociologia, Issue 2, 303-323, Available at: https://www.researchgate.net/publication/336720560 aspects_regarding the military_cultural-historical_heritage in the city_of oradea_romania

35. Morar, C. Lukić, T., Basarin, B., Valjarević, A., Vujičić M., Niemets, L., Telebienieva, I., Boros, L., Nagy, G. (2021). Shaping Sustainable Urban Environments by Addressing the Hydro-Meteorological Factors in Landslide Occurrence: Ciuperca Hill (Oradea, Romania). International Journal of Environmental Research and Public Health, 18(9), 5022; https://doi.org/10.3390/ijerph18095022

36. Morar, C., Nagy. G., Boros, L., Gozner, M., Niemets, L., Sehida, K. (2021). Heritage, Culture and Regeneration of the former Military Areas in the city of Oradea (Romania). Architektúra \& urbanizmus, 55, 1-2.

37. Nemets, L., Kobylin, P., Segida, K. (2014). Analysis of development trajectory for social infrastructure of Kharkiv region. Actual Problems of Economics, 161 (11), 409-418.

38. Niemets, K., Kliuchko, L., Kulieshova, G. (2015). Features of social and geographical researches of health care system of the border region. Economic Annals-XXI, 1-2 (1), 93-97. Available at: http://nbuv.gov.ua/UJRN/ecchado_2015 1-2(1)__24

39. Niemets, K., Sehida, K., Niemets, L., Krainyukov, O., Telebienieva, I., Kobylin, P. (2018). Some Issues of the Formation and Implementation of the Development Strategies of Ukraine's Regions Taking into Account European Experience. Proceedings of the 32nd International Business Information Management Association Conference (November 15-16, 2018, Seville, Spain,), 314-327. Available at: https://ibima.org/accepted-paper/formation-andimplementation-of-the-development-strategies-of-ukraines-regions-in-the-aspect-of-eurointegration/

40. Niemets, K., Yakovleva, J., Niemets, L. (2014). The analysis of the research results of sociogeographical features of Donetsk region's social development as an old industrial region. Actual Problems of Economics, 162 (12), $271-280$.

41. Niemets, L., Mezentsev, K., Morar, C., Sehida, K., Husieva, N., Peresadko, V. (2018). Innovation and Investment Potential of Region as a Factor of its" Smart Transformation": Kharkiv Region Case Study (Ukraine). Visnyk of V. N. Karazin Kharkiv National University, series "Geology. Geography. Ecology", 49, 137-159, https://doi.org/10.26565/2410-7360-2018-49-11

42. Popchenko, T. On the priority areas for improving the domestic health sector.Analytical note. National Institute for Strategic Studies. Available at: http://old2.niss.gov.ua/articles/480/

43. Quantitative and qualitative analysis of Ukraine's emergency medical services to assess current capacities and opportunities for future development (2020). World Health Organization. Regional Office for Europe. Available at: https://www.euro.who.int/en/countries/ukraine/publications/quantitative-and-qualitative-analysis-of-ukrainesemergency-medical-services-to-assess-current-capacities-and-opportunities-for-future-development-2020

44. Sheiman, I. (2013) Rocky road from the Semashko to a new health model. Bull World Health Organ, 91, 320-321, http://dx.doi.org/10.2471/BLT.13.030513

45. Slaybaugh, C. (n.d.). International Healthcare Systems: The US Versus the World. Axene Health Partners. Available at: https://axenehp.com/international-healthcare-systems-us-versus-world/

46. Stankov, U., Vasiljević, Đ., Jovanović, V., Kranjac, M., Vujičić, M., Morar, C. \& Bucur, L. (2019). Shared Aerial Drone Videos - Prospects and Problems for Volunteered Geographic Information Research. Open Geosciences, 11(1), 462-470, https://doi.org/10.1515/geo-2019-0037

47. Tomini, S. M., Groot, W., Pavlova, M., Tomini, F. (2015). Paying out-of-pocket and informally for health care in Albania: the impoverishing effect on households. Frontiers in Public Health, 28 August 2015, https://doi.org/10.3389/fpubh.2015.00207

48. TOP 10: Countries with the best healthcare system. Available at: https://www.cignaglobal.com/blog/healthcare/top10-countries-best-healthcare-system

49. Tran, L.D., Zimmerman, F.J., Fielding, J.E. (2017). Public health and the economy could be served by reallocating medical expenditures to social programs. SSM - Population Health, 3, 185-191, https://doi.org/10.1016/j.ssmph.2017.01.004

50. Ukraine: review of health financing reforms 2016-2019 (2019). WHO-World Bank Joint Report. Available at: https://www.euro.who.int/_data/assets/pdf_file/0018/425340/WHO-WB-Joint-Report_UKR_Full-report_Web.pdf.

51. Vujičić, D. M., Vasiljević, D. A., Hose, T.A., Tasić, N., Morar, C., Đurić, A., Marković, S. B. (2018). A multi-criteria decision analysis with special reference to loess and archaeological sites in Serbia (Could geosciences and archaeology cohabitate?).Open Geosciences, 10(1), 333-343, https://doi.org/10.1515/geo-2018-0026

52. World Bank national accounts data, and OECD National Accounts data files. https://data.worldbank.org/indicator/NY.GDP.MKTP.CD?view=chart

53.Xiao, Y., Chen, X., Li, Q., Jia, P., Li, L., Chen, Z. (2021). Towards healthy China 2030: Modeling health care accessibility with patient referral. Social Science \& Medicine, 276, May 2021, 113834, https://doi.org/10.1016/j.socscimed.2021.113834 